Kinga Machowicz

Katolicki Uniwersytet Lubelski Jana Pawła II

Robert Tabaszewski

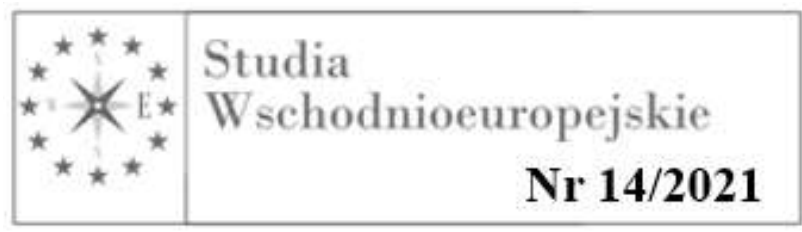

Katolicki Uniwersytet Lubelski Jana Pawła II

\title{
Porozumienie Republiki Armenii i Republiki Azerbejdżanu z 9 listopada 2020 r. w sprawie Górskiego Karabachu - charakter prawny oraz implikacje polityczne
}

listopada 2020 r. w późnych godzinach wieczornych wydano oświadczenie Prezydenta
Republiki Azerbejdżanu, Premiera Republiki Armenii i Prezydenta Federacji Rosyjskiej ${ }^{346}$. Strony wojujące (Armenia i Azerbejdżan) zobowiązały się w nim do całkowitego zawieszenia broni i ustania wszelkich działań wojennych w strefie konfliktu zbrojnego o Górski Karabach. Oświadczenie zawiera również szereg interesujących kwestii z punktu widzenia geopolitycznego, militarnego, ekonomicznego, a także prawnomiędzynarodowego. Przedmiotem tego artykułu jest analiza Porozumienia zarówno pod kątem formalno-prawnym, jak i pod względem poszczególnych merytorycznych treści kształtujących konsekwencje polityczne, jakie niosą poszczególne w nim zawarte regulacje. Z uwagi na wage zagadnienia, jakim jest skala konfliktu w Górnym Karabachu i zaangażowanie poszczególnych stron, Porozumienie z listopada 2020 r. można porównywać $\mathrm{z}$ innego typu dokumentami zawieranymi przez Republikę Azerbejdżanu i Republikę Armenii, w tym kończącymi wojnę z 1994 r. oraz konflikt w Górskim Karabachu z 2016 r. ${ }^{347}$, a także $\mathrm{z}$ oświadczeniami sygnowanymi przez władze rosyjskie, w tym rozmowami prowadzonymi pod egidą grupy mińskiej $\mathrm{OBWE}^{348}$. Jednak, w odróżnieniu od tych dokumentów, strony konfliktu wydają się nadawać Porozumieniu jakościowo i strategicznie zupełnie nowe znaczenie. Dlatego też celem artykułu jest zbadanie charakteru prawnego i politycznego tego dokumentu, wraz z oceną, w jakim zakresie dokument ten stanowi nową jakość w procesie pokojowym.

\footnotetext{
${ }^{346}$ Statement by President of the Republic of Azerbaijan, Prime Minister of the Republic of Armenia and President of the Russian Federation, http://kremlin.ru/events/president/news/64384, (17.02.2021).

${ }^{347}$ A. Legieć, , Rosyjski rozejm” w Górskim Karabachu, „Polski Przegląd Dyplomatyczny”, 2021, nr 1, s. $92-93$.

348 A. Mortazavian, M. Ghiacy, Regional and International Cooperation to Reduce Nagorno - Karabakh Conflict, "Journal of Politics and Law" 2017, No. 10(2), p. 138.
} 
Postawiona została hipoteza główna, iż Porozumienie Republiki Azerbejdżanu i Republiki Armenii z 9 listopada 2020 r. burzy status quo w regionie Górskiego Karabachu i tworzy fundamenty dla zbudowania zupełnie nowego ładu politycznego w tej części świata. Dla jej weryfikacji autorzy postawili pytania badawcze: 1) Czy Porozumienie ma charakter prawnie zobowiązujący i wiąże wyłącznie strony wojujące? 2) Jaką postać, od strony prawnej, przyjmuje Porozumienie? 3) Czy Porozumienie zawiera instrumenty wymuszenia jego postanowień? 4) Jaki jest formalny, a jaki realny status Federacji Rosyjskiej jako głównego gwaranta tego Porozumienia? 5) W jakim zakresie intencją stron wojujących było, poprzez podpisanie Porozumienia, stworzenie nowego ładu geostrategicznego w tym regionie - jak dalece było to wypadkową od nich niezależną, reżyserowaną przez zewnętrznych graczy? 6) Czy wprowadzenie rosyjskich sił rozjemczych w wyniku zawartego Porozumienia wyklucza możliwość podjęcia szerszej interwencji humanitarnej przez społeczność międzynarodową? Badania, których wyniki przedstawiono w niniejszym artykule, zostały przeprowadzone przy wykorzystaniu metody desk research. Metodę tę wybrano ze względu na połączenie zalet analizy treści, analizy danych statystycznych i analizy historycznoporównawczej ${ }^{349}$. Analizie poddano dokumenty $\mathrm{z}$ zakresu międzynarodowego prawa konfliktów zbrojnych (MPKZ) oraz Międzynarodowego Prawa Humanitarnego (MPH), wykorzystano także polsko- i obcojęzyczną literaturę przedmiotu. Rozważania ograniczono głównie do okresu 2020-2021 r., bezpośrednio związanego z przyjętym Porozumieniem. Praca powstała $\mathrm{w}$ większości na podstawie analizy dokumentów stron wojujących, a także w oparciu o analizę Porozumienia z 9 listopada 2020 r., jak również wykonującego je trójstronnego Porozumienia z 11 stycznia 2021 r. Wykorzystano również dotychczasowe decyzje Europejskiego Trybunału Praw Człowieka (ETPCz) oraz faktyczne działania tzw. grupy mińskiej OBWE w sprawie ${ }^{350}$.

\section{Geneza i okoliczności zawarcia Porozumienia}

Oświadczenie najwyższych władz Republiki Armenii i Republiki Azerbejdżanu z 9 listopada 2020 r. jest kolejnym dokumentem kończącym etap konfliktu zbrojnego o Górski Karabach. Pierwsze tego typu Porozumienie będące zamrożeniem konfliktu i czasowym ustaniem walk po wyczerpującej wojnie z lat 1988 - 1994 zostało zawarte 5 maja

\footnotetext{
349 Z. Bednarowska, Desk research - wykorzystanie potencjatu danych zastanych $w$ prowadzeniu badań marketingowych i badań spolecznych, „Marketing i Rynek” 2015, nr 7, s. 18-19.

${ }^{350}$ Zob. A. Legieć, op. cit., s. 92.
} 
1994 r. w stolicy Kazachstanu, Biszkeku (tzw. Protokół z Biszkeku) ${ }^{351}$. Zostało ono podpisane przez przedstawicieli władz ustawodawczych Republiki Armenii oraz Republiki Azerbejdżanu, ale również nieuznawanej na arenie międzynarodowej Republiki Górskiego Karabachu (ang. Republic of Artsakh) oraz Federacji Rosyjskiej, przewodniczącej (poza Francją i USA) grupie mińskiej OBWE. Od strony politycznej dokument nie stworzył podstaw do zbudowania trwałego pokoju, co potwierdziło wielokrotne łamanie kruchego zawieszenia broni pomiędzy Ormianami i Azerami w 2008 r. Otwarta eskalacja konfliktu nastąpiła 2-4 kwietnia 2016 r. Po tzw. wojnie czterodniowej strony ogłosiły zawieszenie broni i wstrzymanie ognia. Tym razem Porozumienie walczących stron miało charakter prowizorium i sprowadziło się do wydania ustnych oświadczeń przedstawicieli władz Armenii i Azerbejdżanu, które następnie zostały zakomunikowane przez moskiewskie agencje informacyjne. Oficjalne oświadczenie wydali również przedstawiciele Republiki Górskiego Karabachu. Porozumienie i utrzymanie status quo w regionie, po telefonicznym uzgodnieniu stanowisk obu stron, potwierdził następnie prezydent Władimir Putin.

Porozumienie podpisane w Moskwie 9 października 2020 r. przez ministrów spraw zagranicznych Azerbejdżanu i Armenii nie było trwałe i zostało szybko złamane przez obie strony konfliktu. Można wskazać przyczyny tego stanu rzeczy. Przede wszystkim o trwałości rozejmu decydują czynniki polityczne i wojskowe. W rozmowach, przynajmniej oficjalnie, nie uczestniczył przedstawiciel tzw. Republiki Górskiego Karabachu. Co interesujące, zarówno strony, jak i społeczność międzynarodowa, nie miały złudzeń co do możliwości wypracowania trwałego ustania walk. Dlatego przedstawiciele doktryny umowy zawierane 17 października (pod auspicjami grupy mińskiej OBWE) i 25 października 2020 r. (z inicjatywy USA), określali nie mianem rozejmu, czy zawieszenia broni, ale humanitarian truce. Miało to wskazywać na sektorowy, mający na celu wymianę jeńców oraz ciał zmarłych, charakter ewentualnego porozumienia.

Przystąpienie stron do opracowania nowego porozumienia zostało podyktowane azerskim natarciem i zajęciem miasta Szusza. Wydarzeniom tym towarzyszyła ofensywa dyplomatyczna stron konfliktu na forum międzynarodowym, jak również na płaszczyźnie sądowej. Warto zauważyć, że w tym czasie Armenia ${ }^{352}$, a następnie Azerbejdżan ${ }^{353}$,

\footnotetext{
${ }^{351}$ J. Miklasová, The Recent Ceasefire in Nagorno-Karabakh: Territorial Control, Peacekeepers and Question of Status, EJIL:Talk! Blog of the European Journal of International Law, "European Journal of International Law" https://www.ejiltalk.org/the-recent-ceasefire-in-nagorno-karabakh-territorial-control-peacekeepers-andunanswered-question-of-status (17.02.2021).

${ }^{352}$ Zob. Sprawa Armenia przeciwko Azerbejdżanowi, skarga nr 42521/20.

${ }^{353}$ Zob. Sprawa Azerbejdżan przeciwko Armenii, skarga nr 47319/20.
} 
wzajemnie złożyły przeciwko sobie skargi międzypaństwowe do $\mathrm{ETPCz}^{354}$. Do 27 września Armenia wnioskowała również o zastosowania środków tymczasowych przez ETPCz. Już dwa dni później obie strony zostały wezwane przez Trybunał do powstrzymania się od jakichkolwiek środków, w szczególności działań wojskowych, które mogłyby pociągnąć za sobą naruszenie praw wynikających z Europejskiej Konwencji o Ochronie Praw Człowieka i Podstawowych Wolności z 1950 r. ${ }^{355}$ dla ludności cywilnej, w tym pozbawienie jej życia i zdrowia ${ }^{356}$. Wdrożone środki tymczasowe okazały się mało skuteczne, o czym świadczą kolejne skargi międzypaństwowe, wniesione do ETPCz 15 stycznia 2021 r. przez Azerbejdżan ${ }^{357}$ i 5 lutego 20201 r. przez Armenię ${ }^{358}$, czyli już po zawarciu Porozumienia z 9 listopada 2020 r. ${ }^{359}$ Niską efektywność działań podejmowanych w ramach grupy mińskiej OBWE, instytucji Rady Europy, a także bezczynność UE, przy nasilającej się ofensywy Azerbejdżanu wykorzystała Rosja. Już na początku listopada 2020 r. jednostronnie, $\mathrm{z}$ pominięciem innych głównych graczy w regionie, w tym zwłaszcza Turcji, rozpoczęła własną grę dyplomatyczną. Efektem szeroko zakrojonych działań, obejmujących również działania humanitarne i operacyjne, było nakłonienie stron wojujących do wydania wspólnego „oświadczenia" ${ }^{\text {360 }}$. $\mathrm{Na}$ skalę zastosowanych środków wskazuje również udział W sygnowanym Porozumieniu z 9 listopada najwyższych przedstawicieli władz: prezydenta Republiki Azerbejdżanu - Ilhama Alijewa, premiera Republiki Armenii - Nikola Pasziniana, a także Federacji Rosyjskiej - prezydenta Władimira Putina. Było to ze wszech miar niecodzienne wydarzenie, nie tylko $\mathrm{z}$ racji na panujące $\mathrm{w}$ regionie obostrzenia związane z pandemią COVID-19. Przede wszystkim z uwagi na wzajemną niechęć przywódców Azerbejdżanu i Armenii do siebie. Dlatego też zostało podpisane podczas wideokonferencji

\footnotetext{
354 Warto również w tym miejscu wskazać, na inne „zamaskowane” skargi indywidualne obywateli Azerbejdżanu i Armenii składanych odpowiednio przeciwko Armenii i Azerbejdżanowi. Dokładna analiza ich treści pozwala na stwierdzenie, że praktyce były to skargi dotyczące sporu pomiędzy państwami. Należą o nich: sprawa Chiragov i inni przeciwko Armenii, skarga nr 13216/05 oraz sprawa Sargsyan przeciwko Azerbejdżanowi, skarga nr 40167/06.

${ }^{355}$ Konwencja o Ochronie Praw Człowieka i Podstawowych Wolności sporządzona w Rzymie dnia 4 listopada 1950 r., zmieniona następnie Protokołami nr 3, 5 i 8 oraz uzupełniona Protokołem nr 2.

${ }^{356}$ Zob. ECHR Press Release, The Court makes a statement on requests for interim measures concerning the conflict in and around Nagorno-Karabakh, ECHR 314 (2020), 4.11.2020.

${ }^{357}$ Zob. sprawa Azerbejdżan przeciwko Armenii, skarga nr 47319/20.

${ }^{358}$ Zob. sprawa Armenia przeciwko Azerbejdżanowi, skarga nr 42521/20.

${ }^{359}$ Zob. ECHR Press Release, Receipt of applications in two inter-State cases related to the conflict in NagornoKarabakh, ECHR 314 (2020), 4.02.2021.

${ }^{360}$ Warto w tym kontekście zauważyć, że w treści porozumienia użyto sformułowania „statement”, a nie ,agreement".
} 
i natychmiast podane na stronie internetowej Kremla. Porozumienie w części dotyczącej zaprzestania walk zostało wprowadzone ze skutkiem natychmiastowym ${ }^{361}$.

\section{Charakter prawny Porozumienia}

Porozumienie jest zwięzłym, dziewięciopunktowym oświadczeniem, poprzedzonym jednozdaniowym wstępem. Oświadczenie zostało sygnowane przez najwyższe władze stron wojujących. Analiza Porozumienia wskazuje, że mamy do czynienia z nową jakością prawną, za którą stoją odpowiednie środki mające na celu ustanowienie nowego ładu w regionie. Rozejm i zawieszenie broni, jako porozumienia zawierane pomiędzy stronami wojującymi należą do źródeł międzynarodowego prawa humanitarnego (MPH) ${ }^{362}$, a w przypadku ustanowienia rozejmu o charakterze trwałym, również do źródeł prawa międzynarodowego publicznego $^{363}$. Bez wątpienia obie te gałęzie prawa oddziałują również na międzynarodowe stosunki polityczne pomiędzy Republiką Armenii a Republiką Azerbejdżanu. Mają bowiem na celu podjęcie kroków zmierzających do czasowego lub całkowitego zakończenia konfliktu $^{364}$. W doktrynie prawa międzynarodowego wyraźnie odróżnia się rozejm od porozumienia o zawieszeniu broni. Kwestie dotyczące charakteru prawnego porozumienia stron wojujących reguluje przede wszystkim Międzynarodowa konwencja dotycząca praw i zwyczajów wojny lądowej z 10 października 1907 r., czyli IV Konwencja haska. Zgodnie z jej art. 37 porozumienia stron mogą być bądź ogólne (rozejmy) lub miejscowe (zawieszenia broni). Pierwsze wstrzymują wszelkie działania wojenne stron wojujących, drugie odnoszą tylko skutek pomiędzy niektórymi częściami armii wojujących, jak również na określonej przestrzeni. Zarówno rozejm, jak i porozumienia o zawieszeniu broni, w świetle MPKZ są formą porozumienia obowiązującego inter partes pomiędzy stronami wojującymi, ale rodzącymi również skutki o charakterze erga omnes na arenie międzynarodowej. Uznanie danego porozumienia za rozejm bądź porozumienie o zawieszeniu aktualizuje się przy interpretacji konkretnych postanowień porozumień stron wojujących. Ma to znaczenie przy

\footnotetext{
361 Pomimo, że od momentu podpisania i wejścia w życie Porozumienia z 9 listopada 2020 r., doszło już wielokrotnie do złamania jego postanowień, to obecność wojsk rosyjskich, działa w sposób mrożący na strony konfliktu; zapobiegła eskalacji konfliktu. Zob. Złamane porozumienie w Górskim Karabachu. Doszło do starć. https:/www.rp.pl/Konflikty-zbrojne/201219779-Zlamane-porozumienie-w-Gorskim-Karabachu-Doszlo-dostarc.html (17.02.2021).

${ }^{362}$ L. Antonowicz, Podręcznik prawa międzynarodowego, Warszawa 2003, s. 242-243; J. Dobrowolska-Polak, Ludzie w cieniu wojny. Ludność cywilna podczas wspótczesnych konfliktów zbrojnych, Poznań 2011, s. 71-74.

${ }^{363}$ K. Orzeszyna, M. Skwarzyński, R. Tabaszewski, Prawo międzynarodowe praw człowieka, Warszawa 2020, s. 234.

364 Konwencja Dotyczącej Praw i Zwyczajów Wojny Lądowej, Haga, 18 października 1907 r., dalej jako: Konwencja haska.
} 
wykładni oświadczenia z 9 listopada 2020 r. przerywającego od północy, 10 listopada 2020 r. czasu moskiewskiego, działania wojenne ${ }^{365}$.

Zdecydowanie dalej idące konsekwencje niesie uznanie danego porozumienia stron wojujących za rozejm. Według Bogusława Banaszaka, rozejmem należy nazywać zawartą na piśmie, bezterminową umowę pomiędzy państwami wojującymi, której celem jest zakończenie działań wojennych lub stanu wojny i która oprócz spraw wojskowych obejmuje również kwestie terytorialne, ekonomiczne i polityczne ${ }^{366}$. Rozejm zwykle poprzedza zawarcie przez strony traktatu pokojowego. Oświadczenie wstrzymuje działania wojenne za wzajemną umową stron wojujących. W praktyce ustanowienie porozumienia pomiędzy Armenią a Azerbejdżanem byłoby niemożliwe bez mediacji państw trzecich, w szczególności bezpośrednio zainteresowanej konfliktem w regionie Federacji Rosyjskiej, a wcześniej również Turcji, ostatecznie wyłączonej $\mathrm{z}$ procesu stabilizacyjnego $\mathrm{w}$ regionie ${ }^{367}$. Na siłę sprawczą Rosji wskazuje również to, że właśnie rosyjska a nie azerska czy ormiańska wersja językowa Porozumienia, w razie wątpliwości interpretacyjnych, ma stanowić podstawę wykładni. Za uznaniem trójstronnego Porozumienia z 9 listopada 2020 r. za rozejm (a nie za porozumienie o zawieszeniu broni) przemawia ponadto cel zastosowanych w niej środków, tj. zakładających przerwanie walk wszystkich głównych sił konfliktu o Górski Karabach, a nie tylko regularnych wojsk ${ }^{368}$. W międzynarodowym prawie konfliktów zbrojnych wskazuje się, że w chwili zawarcia rozejmu upór przynajmniej jednej ze stron ulega osłabieniu, co znajduje namacalny dowód w postaci strat terytorialnych jednej ze stron $^{369}$, w tym wypadku Armenii. Również układ sił, jaki powstałwskazuje, że dokument ten jest bardziej klasycznym rozejmem, niż porozumieniem tymczasowym typu humanitarian truce. Porozumienie, odmiennie niż dokumenty z maja 1994 r. i kwietnia 2016 r., nie jest sygnowane przez przedstawicieli Republiki Górskiego Karabachu, co burzy również dotychczasową praktykę opisywanych dokumentów sprawie statusu tego regionu. Wszystko to $\mathrm{z}$ dużym prawdopodobieństwem skazuje ten samozwańczy podmiot na zapomnienie prawne i polityczną anihilację.

Porozumienie jest zatem dokumentem tylko w części będącym wypadkową sytuacji stworzonej przez strony konfliktu. W dużej mierze jego projekt został arbitralnie ${ }^{365}$ P. Pieniążek, To nie koniec konfliktu o Górski Karabach, „Polski Przegląd Dyplomatyczny” 2021, nr 1, s. 113.

${ }^{366}$ B. Banaszak, Rozejm, [w:] Encyklopedia prawa, Wydawnictwo C.H. Beck, Warszawa 2007, s. 724.

367 J. Niewiński, Dażenie Federacji Rosyjskiej do utrzymania wpływów na obszarze postradzieckim, „Studia Wschodnioeuropejskie" 2018, nr 9, s. 33-34.

${ }^{368}$ J. Miklasová, op. cit., b.p.

${ }^{369}$; L. Antonowicz, op. cit., s. 243. 
przedstawiony przez rosyjską dyplomację tuż po zajęciu przez Azerbejdżan miasta Szusza i wobec groźby rychłego zajęcia Stepanakertu, stolicy separatystycznego Górskiego Karabachu. Azerbejdżan i Armenia zgodziły się na całkowite zawieszenie broni ze skutkiem natychmiastowym, tj. od północy 10 listopada, jak również na ustanie wszelkich działań wojennych w strefie konfliktu. Oznacza to całkowitą zmianę i ustanowienie nowego ładu terytorialnego w Górskim Karabachu. Wyrazem tej transformacji jest punkt drugi i szósty Porozumienia dotyczący zmian terytorialnych. Zakładały one „zwrócenie” Republice Azerbejdżanu regionu Kalbajar do 15 listopada 2020 r., regionu Agdam do 20 listopada 2020 r., a także regionu Lachin do 1 grudnia 2020 r. Ponadto, w świetle punktu pierwszego Azerbejdżan i Armenia miały zatrzymać się na swoich stanowiskach, które zajmowały na dzień 9 listopada $2020 \mathrm{r}$.

\section{Polityczne implikacje zawartego Porozumienia}

Treść Porozumienia sprawia, że w sumie Azerbejdżan powinien uzyskać kontrolę nad siedmioma prowincjami leżącymi dokoła Górskiego Karabachu ${ }^{370}$. Z punktu widzenia Azerbejdżanu, jest to powrót do macierzy ziem, które zostały utracone w trakcie pierwszej wojny z lat 1988-1994 371 i które z jego i Rady Bezpieczeństwa ONZ punktu widzenia stanowiły ziemie okupowane ${ }^{372}$. Istotne jest uregulowanie dotyczące pozostawienia w obrębie jego faktycznej jurysdykcji miasta Szusza. Miasto aż do 7 listopada 2020 r. pozostawało w rękach nieuznawanej Republiki Górskiego Karabachu. Punkt drugi Porozumienia gwarantuje, że mający powstać tzw. korytarz laczyński (o szerokości $5 \mathrm{~km}$ ), który zapewni połączenie Górskiego Karabachu z Armenią, w żaden sposób nie wpłynie na miasto Szusza i pozostanie pod kontrolą kontyngentu sił pokojowych Federacji Rosyjskiej. Korytarz ten jest z kolei żywotnie istotny dla samej Armenii i diaspory armeńskiej w regionie - łączy Górski Karabach z Armenią. W świetle analizowanego dokumentu jest integralną częścią terytorium Armenii. Zgodnie z ustaleniami stron, w ciągu najbliższych trzech lat zostanie ustalony plan budowy nowej trasy w korytarzu laczyńskim, zapewniającej łączność między Górskim Karabachem a Armenią ${ }^{373}$. Biorąc pod uwagę pozostałe punkty Porozumienia, głównym celem de facto ma być zapewnienie połączenia Chenkendi (dla Ormian: Stepanakert) z

\footnotetext{
${ }^{370}$ Zob. A. Legieć, op. cit., s. 92, 94.

371 S.S. Mammadov, International Law and the Nagorno-Karabakh War: Opinion on Political Aspects, "Polish Political Science Yearbook" 2016, vol. 45, p. 385-390.

${ }^{372}$ J. Miklasová, op. cit., b.p.; Zob. Resolution 853 (1993) adopted by the Security Council at its 3259th meeting, on 29 July 1993, UN. Security Council (48th year : 1993), para 9.

${ }^{373}$ Punkt 6 Porozumienia; Zob. P. Pieniążek, op. cit., s. 114.
} 
Armenią. Warto zauważyć, że samo miasto Stepanakert, czyli największe miasto w regionie obrane za stolicę nieuznawanej Republiki Górskiego Karabachu, pozostanie w rękach separatystów ormiańskich.

Tekst Porozumienia stanowi wręcz unicum $\mathrm{W}$ porównywaniu $\mathrm{z}$ poprzednimi dokumentami przyjmowanymi w trakcie trwania konfliktu, a nawet innych tego typu konfliktów na obszarze postradzieckim. W regionie Górskiego Karabachu wojska rosyjskie nie były nigdy obecne. Teraz ich pobyt jest legitymizowany treścią trójstronnej umowy. Aż pięć z dziewięciu punktów Porozumienia dotyczy rosyjskich gwarancji służących utrzymaniu rozejmu ${ }^{374}$. Punkt pierwszy legitymizuje działania Prezydenta Federacji Rosyjskiej jako głównego architekta nowego układu. Zgodnie z Porozumieniem wzdłuż wspomnianego korytarza laczyńskiego rozlokowany został kontyngent pokojowy Rosji w liczbie 1960 żołnierzy z bronią strzelecką, 90 transporterów opancerzonych, 380 sztuk samochodów i sprzętu specjalnego przeznaczenia. Dodatkowo rosyjski kontyngent stabilizacyjny $\mathrm{w}$ regionie Kelbajar i regionie Agdam miał być rozmieszczany równolegle $\mathrm{z}$ wycofywaniem armeńskich sił zbrojnych ${ }^{375}$. Okres pobytu kontyngentu sił pokojowych Rosji wynosi pięć lat $\mathrm{z}$ automatycznym przedłużeniem na kolejne, pięcioletnie okresy. Teoretycznie każda ze Stron może zadeklarować zamiar zaprzestania stosowania niniejszego postanowienia, a okres takiego wypowiedzenia wynosi sześć miesięcy. Do tego czasu, w świetle przepisów prawa międzynarodowego, każdy atak na stacjonujące tam wojska rosyjskie może być uznany za agresję $\mathrm{w}$ rozumieniu art. 51 Karty Narodów Zjednoczonych ${ }^{376}$. W świetle Porozumienia kontrolę komunikacji transportowej również sprawują w regionie organy Służby Granicznej FSB Rosji. Jak widać, układ granic wraca praktycznie do stanu sprzed upadku Związku Radzieckiego.

Kolejne punkty Porozumienia stanowią jednostronne, bezwarunkowe gwarancje Azerbejdżanu dotyczące zapewnienia bezpieczeństwa ruchu obywateli, pojazdów i towarów w korytarzu laczyńskim „w obu kierunkach”. Nie określono przy tym, o obywateli którego państwa chodzi, a to nie wyklucza mieszkańców nieuznawanej Republiki Górskiego Karabachu. Władze Azerbejdżanu zobowiązały się do tego, że wszystkie połączenia gospodarcze i transportowe w regionie zostają odblokowane. Również Republika Armenii zobowiązała się do zagwarantowania bezpieczeństwa połączeń transportowych między zachodnimi regionami Republiki Azerbejdżanu i Autonomiczną Republiką Nachiczewanu

\footnotetext{
374 J. Miklasová, op. cit., b.p.; P. Pieniążek, op. cit., s. 113.

375 J. Miklasová, op. cit., b.p.; Zob. A. Legieć, op. cit., s. 98.

376 J. Miklasová, op. cit., b.p.; Karta Narodów Zjednoczonych podpisana w San Francisco, 26 czerwca 1945 r.
} 
W celu zorganizowania niezakłóconego ruchu obywateli, pojazdów i towarów w obu kierunkach. Jedynym warunkowym fragmentem Porozumienia jest ten dotyczący zapewnienia budowy nowej komunikacji transportowej łączącej Autonomiczną Republikę Nachiczewanu z zachodnimi regionami Azerbejdżanu, co ma się odbyć „za zgodą stron”. Przy czym niewyjaśnione zostało, czy zgodę na to musi również wyrazić Rosja. Jest to element istotny z punktu widzenia żywotnych interesów Azerbejdżanu, ponieważ region ten stanowi eksklawę graniczącą z Armenią, Turcją, Gruzją oraz Iranem ${ }^{377}$.

Jednoznacznie pozytywnie należy ocenić część Porozumienia zawierającą mechanizmy wprowadzające postanowienia w życie, w tym te postanowienia, które dotyczą kwestii związanych z trybem udzielania pomocy humanitarnej. Strony zobowiązały się bowiem do prowadzenia wymiany jeńców wojennych, zakładników i innych zatrzymanych, jak również ciał zmarłych. Osobny punkt dotyczy kwestii migracyjnych i należy go zaliczyć do sukcesów Azerbejdżanu. Strony uznały bowiem prawo powrotu osób, które w wyniku postanowień z 1994 r. musiały opuścić strony ojczyste. Dotyczy to przesiedleńców (migrantów) wewnętrznych i uchodźców, którzy obecnie wracają na terytorium Górskiego Karabachu i obszarów przyległych. Co istotne, proces ten ma się odbywać pod ścisłą kontrolą Biura Wysokiego UNHCR. W celu zwiększenia skuteczności kontroli realizacji porozumień przez strony konfliktu, powołane zostało również Pokojowe Centrum Kontrolujące Zawieszenie Broni w Górskim Karabachu. Jednak w praktyce, to obie strony będą uzależnione przede wszystkim od pomocy żołnierzy rosyjskich decydujących w kwestiach dotyczących życia codziennego mieszkańców regionu.

Wykładnia Porozumienia z 9 listopada 2020 r., wskazuje, że jest to dokument wywierający bezpośrednie skutki prawne pomiędzy trzema stronami, w zasadniczy sposób oddziałuje na sytuację geostrategiczną całego regionu, jak również może oddziaływać na państwa regionu ${ }^{378}$. Porozumienie z 9 listopada 2020 r. należy oceniać nie tylko pod względem oceny formalnej treści w niej zawartej, ale również badając zamiar i charakter, jaki każda ze stron zamierza nadać takiemu dokumentowi. Niektórych istotnych postanowień explicite nie zawarto $\mathrm{w}$ treści dokumentu, od innych natomiast celowo odstąpiono. Do najważniejszych konsekwencji wynikających nie tylko z treści samego dokumentu, ale również z okoliczności faktycznych towarzyszących jego podpisaniu, należy zaliczyć: przejście pod efektywną kontrolę Azerbejdżanu ziem okalających Górski Karabach, które znajdowały się do tej pory pod kontrolą separatystów ormiańskich; powstanie nowej

\footnotetext{
377 J. Miklasová, op. cit., b.p.; Zob. A. Legieć, op. cit., s. 99.

378 J. Miklasová, op. cit., b.p.
} 
przestrzeni prawnej ${ }^{379}$; rozmieszczenie rosyjskich sił na terytorium dotychczasowego konfliktu i zamrożenie konfliktu przynajmniej na czas stacjonowania tych wojsk ${ }^{380}$; powstanie nowej sytuacji geostrategicznej dla państw sąsiadujących, w tym dla Turcji, Gruzji i Iranu; czasowe zażegnanie ryzyka interwencja humanitarnej w tzw. Republice Górskiego Karabachu; jak również dyplomatyczną alienację OBWE, UE i USA jako potencjalnych mediatorów w konflikcie ${ }^{381}$.

Bez wątpienia najważniejszym i bezpośrednim skutkiem rozejmu jest zmiana układu sił w regionie, która nastąpiła poprzez przejęcie faktycznej kontroli nad siedmioma regionami przez Azerbejdżan ${ }^{382}$. Powoduje to poważne konsekwencje dla prawie półmilionowej azerskiej ludności cywilnej, której zapewniono możliwość powrotu na tereny okalające Górski Karabach. W szczególności chodzi o osoby, które uciekły w czasie rozpadu ZSRR lub też zostały wysiedlone po 1994 r. oraz spadkobierców tych osób. Porozumienie nie rozstrzyga jednak wszystkich problemów dotyczących statusu całego terytorium. W szczególności nie odniesiono się - nawet w sposób pośredni - do statusu Republiki Górskiego Karabachu, którego faktyczne władztwo na posiadanym terytorium zostało znacznie okrojone ${ }^{383}$. Choć od strony prawnomiędzynarodowej, terytorium to formalnie przynależy do Azerbejdżanu, to status prawny tego obszaru nie został po 9 listopada 2020 r. - podobnie zresztą jak miało to miejsce w latach 1994-2016 - w żaden sposób potwierdzony ${ }^{384}$.

Porozumienie z 9 listopada 2020 r. milczy również w kwestii możliwości zastosowania interwencji humanitarnej ${ }^{385}$. Część ekspertów wyraża opinię, że etyczna i sprawiedliwa $\mathrm{w}$ swej istocie interwencja humanitarna powinna uzyskać wyraźną prawną legitymację, najlepiej w formie porozumienia, analogicznego jak Porozumienie z $2020 \mathrm{r}^{386}$ Tego rodzaju argumentacja budzi jednak obawy, iż pod pretekstem interwencji humanitarnej

\footnotetext{
${ }^{379}$ W nowej sytuacji prawnej prawdopodobne staną się próby wzajemnego dochodzenie roszczeń przez obie strony na drodze sądowej i w oparciu o arbitraż międzynarodowy. Pozostaje również kwestia dochodzenia reparacji wojennych i odszkodowań dla ofiar konfliktu.

${ }^{380}$ P. Pieniążek, op. cit., s. 115.

${ }^{381}$ J. Miklasová, op. cit., b.p.; A. Legieć, op. cit., s. 97.

382 P. Pieniążek, op. cit., s. 113-114.

${ }^{383}$ Zob. A. Legieć, op. cit., s. 96-97.

${ }^{384}$ Fakt ten należy traktować jako wybieg taktyczny ze strony rosyjskiej, która w przyszłości może wykorzystać ten fakt podczas konstruowania umowy o przedłużeniu obecności swoich sił na tym terenie. Por. S. Kolarz, Status prawny Górskiego Karabachu - porównanie ze statusem prawnym Kosowa, „Folia Iuridica Universitatis Wratislaviensis" 2016, vol. 5 (1), s. 124-125.

${ }^{385}$ M.N. Shaw, Prawo międzynarodowe, Warszawa 2000, s. 595-596.

386 Wskazuje się także, iż przestrzeganie praw człowieka jest tak samo ważnym celem działania ONZ, jak zapewnienie międzynarodowego pokoju i bezpieczeństwa, zaś art. 1 (3) i art. 56 Karty NZ nakładają na państwa prawne zobowiązanie do współpracy w celu promocji praw człowieka.
} 
niektóre państwa regionu, takie jak Rosja i Turcja, mogą dążyć do realizacji partykularnych interesów i podejmować działania, które zasługiwałby na miano sprzecznej z prawem międzynarodowym ${ }^{387}$.

Warto również zauważyć, że weryfikacja przesłanek i kryteriów, których spełnienie nadawałoby danej interwencji humanitarnej cechę legalności, jest w praktyce trudna do zrealizowania. Dlatego też konieczna jest zgoda państw regionu, w którym dokonuje się interwencji, bądź w której stacjonując wojska stabilizacyjne. Ten ostatni przypadek zachodzi właśnie w Górskim Karabachu na podstawie porozumienia z 2020 r. Wydaje się, że zmiana status quo, nawet $\mathrm{w}$ razie gwałtownego wznowienia walk zbrojnych, poprzez przeprowadzenia militarnej interwencji humanitarnej wydaje się mało prawdopodobna ${ }^{388}$. Porozumienie z 9 listopada 2020 r. wprawdzie nie wyklucza takiej możliwości, ale faktyczne działania Rosji, w tym sprawne umiejscowienie wojsk stabilizacyjnych, przy niewielkiej aktywności pozostałych uczestników formatu mińskiego oraz bierności dyplomacji UE, ewentualną szerszą interwencję międzynarodową czyni praktycznie niemożliwą ${ }^{389}$. Stąd też najbardziej prawdopodobnym scenariuszem jest poszerzenie rosyjskiej obecności w regionie bądź też, co już zdecydowanie mniej prawdopodobne, poszerzenie tego formatu o obecność turecką. Jednak, aby tak się stało, musiałoby zostać zawarte nowe, poszerzone, czterostronne porozumienie uzupełniające rozejm z $2020 \mathrm{r}$.

W Porozumieniu nie zawarto również precyzyjnych regulacji dotyczących odmrażania wzajemnych azersko-armeńskich stosunków w regionie. Niestabilność stała się w ostatnich latach skutecznym narzędziem Moskwy w walce o wpływy w regionie, co widać wyraźnie nie tylko w kontekście Górskiego Karabachu, ale innych sporów terytorialnych w regionie, takich jak: Naddniestrze, Abchazja i Osetia Południowa czy Ukraina ${ }^{390}$. Jak do tej pory Rosja efektownie w sferze wizerunkowej wykorzystuje otrzymany mandat, bo już 11 stycznia

\footnotetext{
${ }^{387}$ Zob. A. Legieć, op. cit., s. 98.

${ }^{388}$ Prognoza opiera się na wyrażonym przez K. Pawłowskiego poglądzie, że ewentualna interwencja w istotny sposób zmieniałaby spoczywające na państwach prawne ograniczenia w zakresie odwołania się do zbrojnej siły w stosunkach międzynarodowych, co stanowiłoby poważny regres wobec wyraźnych w tej kwestii postanowień Karty NZ i powodowałby nieuchronną relatywizację norm prawa międzynarodowego, a dodatkowo zamiast stabilizować środowisko międzynarodowe prowadziłoby raczej do jego większej destabilizacji - zob. K. Pawłowski, Zjawisko interwencji humanitarnej w stosunkach międzynarodowych [w:] Praktyka ochrony praw człowieka, t. II, red. K. Machowicz, Wydawnictwo KUL, Lublin 2013, s. 105.

389 Prezydent Francji, Emmanuel Macron, wielokrotnie zwracał uwagę na konieczność doprecyzowania niektórych postanowień zawartego rozejmu. Ostatni raz czynił to w rozmowie telefonicznej z W. Putinem 10 stycznia 2021 r. tuż przed spotkaniem przywódców Armenii i Azerbejdżanu w Moskwie, zob. J. Miklasová, op. cit., b.p.; Telephone conversation with President of France Emmanuel Macron, http://en.kremlin.ru/events/president/news/64873 (17.02.2021).

${ }^{390}$ P. Marcinkowska, Russia and the Eastern Partnership, „Studia Wschodnioeuropejskie” 2014, nr 5, s. 8.
} 
2021 r., po trójstronnym spotkaniu przywódców Armenii, Azerbejdżanu i Rosji, wydane zostało kolejne, czteropunktowe Oświadczenie uszczegóławiające sposób wykonania rozejmu poprzez powołanie trójstronnej grupy roboczej w celu przywrócenia wszelkich stosunków gospodarczych i transportowych $\mathrm{w}$ regionie ${ }^{391}$. Zatwierdzono $\mathrm{w}$ nim skład podgrup eksperckich. Grupa robocza odpowiada za organizację, realizację i bezpieczeństwo przewozów międzynarodowych przez terytorium Azerbejdżanu i Armenii do 1 marca $2021 \mathrm{r}$. oraz przewozów realizowanych przez Azerbejdżan i Armenię. W oparciu o wypracowane stanowisko Grupa przedstawi listę możliwych, wspólnych działań i harmonogram realizacji odbudowy i budowy nowej infrastruktury transportowej niezbędnej do zapewnienia wysokiego poziomu akceptacji Stron.

W styczniu 2021 r. ustalono również, że pozostałe kierunki udrożnienia i nadzoru nad szlakami w regionie przylegającym do Górskiego Karabachu zostaną określone w osobnym porozumieniu zawartym pomiędzy Armenią a Rosją ${ }^{392}$. Umieszczenie tego punktu wskazuje na uznanie przez Azerbejdżan roli Rosji za głównego mediatora, jak również może stanowić wstęp do szerszego porozumienia się z Rosją głównego patrona Azerbejdżanu, jakim jest Turcja. Prognoza ta jest oparta na potwierdzeniu już w styczniu 2021 r. przez Prezydenta Rosji udziału Turcji w Pokojowym Centrum Kontrolującym Zawieszenie Broni w Górskim Karabachu. Rola Turcji w rozwiązaniu tego konfliktu w pewnym sensie ulegnie zatem zwiększeniu. Nadal jednak otwartą kwestią pozostaje to, na ile będzie to realne oddziaływanie, a na ile kurtuazja inspirowana przez Rosję - państwo, które przy tej samej okazji może rozgrywać swoje niełatwe do pogodzenia interesy. Z jednej strony utrzymanie roli dominującej siły sprawczej w regionie, a z drugiej - zbliżenie z Turcją.

\section{Konkluzje}

Porozumienie z 9 listopada 2020 r. jest istotnym instrumentem prawnym, wywołującym skutki prawne nie tylko pomiędzy Republiką Azerbejdżanu i Republiką Armenii. Znacząco zmienia regionalną scenę międzynarodową i tworzy nowy układ sił w regionie okalającym Górski Karabach. Ten krótki i zwięzły dokument zawiera wiele konkretnych rozwiązań, które w razie braku większych napięć i przesilenia politycznego,

\footnotetext{
${ }^{391}$ Press statements following talks with President of Azerbaijan Ilham Aliyev and Prime Minister of Armenia Nikol Pashinyan, http:/en.kremlin.ru/events/president/news/64880 (17.02.2021); Statement by President of the Republic of Azerbaijan, Prime Minister of the Republic of Armenia and President of the Russian Federation, 11 January 2021 https://president.az/articles/50070 (17.02.2021).

${ }^{392}$ Meeting with Prime Minister of Armenia Nikol Pashinyan, http://en.kremlin.ru/events/president/news/64883 (17.02.2021).
} 
mogłyby wprowadzić przynajmniej w miarę trwały pokój w regionie. Analiza tekstu i okoliczności zawarcia rozejmu wskazuje, że został opracowany pod wydatnym wypływem dyplomacji rosyjskiej. Strona rosyjska jest również jego gwarantem. Zawarty rozejm odsuwa w czasie możliwość stworzenia szerszej koalicji mogącej dokonać interwencji humanitarnej w nieuznawanej Republice Górskiego Karabachu, którego obszar operacyjny został znacznie zmniejszony na rzecz Azerbejdżanu. Jednak o tym jak bardzo trwały będzie zawarty rozejm, będą decydowały nie tylko strony sporu, ale również czynniki niezależne od samych stron konfliktu, w szczególności obecność wojsk rosyjskich w regionie, poszerzona o ewentualne wsparcie tureckie w nowo powstałym Pokojowym Centrum Kontrolującym Zawieszenie Broni.

\section{Streszczenie:}

Przedmiotem artykułu uczyniono analizę rozejmu pomiędzy Armenią i Azerbejdżanem zawartego pod auspicjami Rosji. Zbadano zagadnienie, w jakim stopniu dokument ten stanowi nową jakość w procesie budowania nowego ładu politycznego w regionie Górskiego Karabachu, a w jakim jest inspirowany polityką innych graczy tego regionu. W pierwszej części przedstawiono okoliczności, w jakich doszło do porozumienia, a następnie dokonano klasyfikacji tego dokumentu pod względem prawnym. W kolejnej części dokonano szczegółowej analizy treści poszczególnych punktów porozumienia, zobowiązań stron konfliktu, jak również roli Rosji. Artykuł kończą rozważania na temat potencjalnych implikacji w sferze politycznej wynikających z realizacji poszczególnych postanowień tego porozumienia przez Armenię i Azerbejdżan.

\section{Slowa kluczowe:}

Armenia, Azerbejdżan, Górski Karabach, Porozumienie o zawieszeniu broni w Górskim Karabachu, porozumienia o zawieszeniu broni, prawo międzynarodowe, rosyjskie siły pokojowe

\section{Key words:}

Armenia, Azerbaijan, Nagorno-Karabakh, Nagorno-Karabakh ceasefire agreement, armistice agreements, international law, Russian peacekeeping forces.

\section{Bibliografia:}

1. Antonowicz L., Podręcznik prawa międzynarodowego, Warszawa 2003

2. Banaszak B., Rozejm, [w:] Encyklopedia prawa, Wydawnictwo C.H. Beck, Warszawa 2007. 
3. Bednarowska Z., Desk research - wykorzystanie potencjalu danych zastanych $w$ prowadzeniu badań marketingowych i badań społecznych, ,Marketing i Rynek” 2015, nr 7.

4. Dobrowolska-Polak J., Ludzie $w$ cieniu wojny. Ludność cywilna podczas współczesnych konfliktów zbrojnych, Poznań 2011.

5. ECHR Press Release, Receipt of applications in two inter-State cases related to the conflict in Nagorno-Karabakh, ECHR 314 (2020).

6. ECHR Press Release, The Court makes a statement on requests for interim measures concerning the conflict in and around Nagorno-Karabakh, ECHR 314 (2020), 4.11.2020.

7. Karta Narodów Zjednoczonych, San Francisco, 26 czerwca 1945 r.

8. Kolarz S., Status prawny Górskiego Karabachu - porównanie ze statusem prawnym Kosowa, „Folia Iuridica Universitatis Wratislaviensis” 2016, vol. 5 (1).

9. Konwencja Dotycząca Praw i Zwyczajów Wojny Lądowej, Haga, 18 października $1907 \mathrm{r}$.

10. Konwencja o Ochronie Praw Człowieka i Podstawowych Wolności sporządzona w Rzymie dnia 4 listopada 1950 r., Dz.U. z 1993 r. Nr 61, poz. 284 ze zm.

11. Legieć A., „Rosyjski rozejm” w Górskim Karabachu, „Polski Przegląd Dyplomatyczny", 2021, nr 1.

12. Mammadov S.S., International Law and the Nagorno-Karabakh War: Opinion on Political Aspects, "Polish Political Science Yearbook" 2016, vol. 45.

13. Marcinkowska P., Russia and the Eastern Partnership, „Studia Wschodnioeuropejskie" 2014, $\mathrm{nr} 5$.

14. Miklasová J., The Recent Ceasefire in Nagorno-Karabakh: Territorial Control, Peacekeepers and Question of Status, "EJIL:Talk!" < https://www.ejiltalk.org/>.

15. Mortazavian A., M. Ghiacy, Regional and International Cooperation to Reduce Nagorno - Karabakh Conflict, "Journal of Politics and Law" 2017, No. 10(2).

16. Niewiński J., Dażenie Federacji Rosyjskiej do utrzymania wpływów na obszarze postradzieckim, ,Studia Wschodnioeuropejskie” 2018, nr 9.

17. Orzeszyna K., Skwarzyński M., Tabaszewski R., Prawo międzynarodowe praw człowieka, Warszawa 2020.

18. Pawłowski K., Zjawisko interwencji humanitarnej w stosunkach międzynarodowych [w:] Praktyka ochrony praw czlowieka, t. II, red. K. Machowicz, Wydawnictwo KUL, Lublin 2013.

19. Pieniążek P., To nie koniec konfliktu o Górski Karabach, „Polski Przegląd Dyplomatyczny" 2021, nr 1.

20. Resolution 853 (1993) adopted by the Security Council at its 3259th meeting, on 29

21. Shaw M.N., Prawo międzynarodowe, Warszawa 2000.

22. Sprawa Armenia przeciwko Azerbejdżanowi, skarga nr 42521/20.

23. Sprawa Armenia przeciwko Azerbejdżanowi, skarga nr 42521/20.

24. Sprawa Azerbejdżan przeciwko Armenii, skarga nr 47319/20.

25. Sprawa Azerbejdżan przeciwko Armenii, skarga nr 47319/20.

26. Sprawa Chiragov i inni przeciwko Armenii, skarga nr 13216/05.

27. Sprawa Sargsyan przeciwko Azerbejdżanowi, skarga nr 40167/06. 
28. Statement by President of the Republic of Azerbaijan, Prime Minister of the Republic of Armenia and President of the Russian Federation, $<$ http://kremlin.ru/ $>$.

29. Złamane porozumienie w Górskim Karabachu. Doszło do starć, <https://www.rp.pl>. 